Boise State University

ScholarWorks

Literacy, Language, and Culture Faculty

Publications and Presentations

Department of Literacy, Language, and Culture

$12-2018$

\title{
A Content Analysis of Visuals in Elementary School Textbooks
}

Daibao Guo

Boise State University

Katherine Landau Wright

Boise State University

Erin M. McTigue

University of Stavanger

This document was originally published in The Elementary School Journal by The University of Chicago Press.

Copyright restrictions may apply. doi: 10.1086/700266 


\title{
A CONTENT ANALYSIS OF VISUALS IN ELEMENTARY SCHOOL TEXTBOOKS
}

\begin{abstract}
A B S T RA C T
Although visual complexity is increasing and graphics are essential to support readers' comprehension of disciplinary texts, visual literacy receives scant attention. Research suggests that effectively instructing students to interpret discipline-specific graphics would yield better comprehension. However, before this line of inquiry can be enacted, we must determine the characteristics of graphics in contemporary content textbooks. Therefore, this content analysis evaluated graphics within third- and fifth-grade science and social studies textbooks. We coded 3,844 graphics by type and function and compared findings between disciplines using chi-square and post hoc comparison tests. Overall, graphics were coded into 9 major types (photographs being most frequent) and 54 subtypes, indicating a diversity of graphics. When comparing disciplines, science textbooks contained more diagrams and photographs, and graphics more often functioned representationally. Social studies presented both a wider variety of graphics and more interpretationally challenging graphics. Implications for disciplinary literacy and instruction are discussed.
\end{abstract}

\author{
Daibao Guo \\ Katherine Landau \\ Wright \\ BOISE STATE UNIVERSITY
}

Erin M. McTigue

UNIVERSITY OF

STAVANGER

S our understanding of disciplinary literacy and text complexity has become more nuanced, have we overlooked any key aspects? We argue: Yes, the visuals. Recently, Common Core State Standards, as well as a growing emphasis on STEM education and disciplinary literacy in elementary

THE ELEMENTARY SCHOOL JOURNAL

Volume 119, Number 2. Published online October 19, 2018

(C) 2018 by The University of Chicago. All rights reserved. 0013-5984/2018/11902-0003 $\$ 10.00$ 
school, have resulted in informational books assuming a progressively prominent role in elementary literacy. Accordingly, students need highly developed skills in genre conventions and structures to navigate these texts (Duke \& Billman, 2009; Pappas, 2006). Meanwhile, researchers have also documented the increasing density and complexity of visuals in elementary texts (McTigue \& Flowers, 2011; Walpole, 1998) and trade books (Coleman \& Dantzler, 2016). However, these lines of research (disciplinary and visual literacy) rarely cross. To advance both, we must consider the disciplinespecific uses of visuals, because constructing meaning from modern texts increasingly relies on understanding graphical displays.

Drawing from cognitive psychology and child development, we analyze the visuals within social studies and science textbooks frequently presented to U.S. elementary students. Convergent evidence demonstrates that well-designed visuals can improve learning (e.g., Hannus \& Hyönä, 1999; Mayer \& Gallini, 1990). However, gaining such benefits from visuals requires knowledge and strategy. Graphic comprehension makes a unique contribution to reading comprehension, beyond the contributions of well-documented factors (e.g., word reading, vocabulary; Roberts, Norman, \& Cocco, 2015). Yet visual literacy is not a generic skill because comprehending a specific visual depends on its clarity, format, and content (Palincsar \& Duke, 2004). For example, reading a time line in social studies requires the reader to know that lines and arrows represent passage of time, whereas the lines and arrows in a water cycle diagram represent water's movement - a distinctly different construct. To fully access such knowledge, readers must receive discipline-specific instruction in decoding visuals. However, before designing instruction, we must understand what types of visual features students will frequently encounter in content-area school textsthe purpose of this research.

Additionally, when analyzing graphics, we recognize that with the advancement of publishing, both the frequency and the complexity of visuals have increased. Simple frequency counts are insufficient to capture the multilayered displays in modern texts. Therefore, analogous to how the concept of text complexity (e.g., Fisher \& Frey, 2012) has supplanted more coarse measures of text difficulty (e.g., readability formula), visual complexity must also be considered. Although visual complexity has historical use in psychology (e.g., Snodgrass \& Vanderwart, 1980), it has typically been applied to a single visual describing both the complexity of the original concept being represented and the conventions of the pictorial representation. However, we conceptualize visual complexity beyond a single representation. Borrowing from text complexity (e.g., Fisher \& Frey, 2012), we believe visual complexity represents an interaction of the density and variety of visuals, the intricacy of individual visual representations, the spatial and semantic integration of text and visuals, formatting features (e.g., captions), and reader characteristics.

Following this concept of visual complexity, it is valuable to categorize the types of visuals, their patterns of use, and the integration between visuals and text. Yet, to date, there have been few systematic efforts to quantify visuals in texts. Slough, McTigue, Kim, and Jennings (2010) conducted an analysis of visuals in sixth-grade science textbooks; however, they considered only one grade level, state, and discipline. More comprehensively, Fingeret (2012) analyzed visuals across both science and social studies textbooks and compared findings by discipline, providing a starting point for this work. However, Fingeret's coding method for function yielded little discrim- 
ination, with more than $64 \%$ of the sample coded as simply extensional (i.e., adding information beyond the text base). Recently, Coleman and Dantzler (2016) produced a detailed visual analysis of science trade books; however, their research ended with books published in 2007. Furthermore, because trade books are a distinct genre, findings may not generalize to textbooks. Additionally, visual use has been evolving at a rapid pace, thus dating these studies.

In an age of high-stakes reading and math testing, and when science instructional time is at historically low levels in elementary schools (Blank, 2012) and the allocation for social studies time has fared even worse (Heafner \& Fitchett, 2012), one may question whether students are reading informational content texts. Although narrative texts continue to dominate (Jeong, Gaffney, \& Choi, 2010), evidence suggests that elementary teachers are integrating informational texts into reading instruction (e.g., Maloch, 2008). Shifting, then, to text use, research indicates that despite increasing informational text and visual content, teachers rarely provide instruction on reading visuals (Coleman, McTigue, \& Smolkin, 2011). Inferring from this practice (or lack thereof) suggests that teachers need professional development in visual literacy, which is logical, because they likely did not receive education in visual literacy (Metros, 2008). Furthermore, we have limited knowledge in terms of younger students' developmental progression of visual literacy, especially children's acquisition of visual literacy skills and the strategies they apply when reading multimodal text. However, before this research line can be acquired, we should fully understand the characteristics of visuals that students frequently encounter.

Before embarking on research regarding how to teach visual literacy, we need to fully understand the visual types and complexity readers will encounter. As such, the purpose of this descriptive study was to systematically categorize the visuals in elementary science and social studies textbooks by analyzing their function and form. Our review of previous work, and underlying empirical research, allowed us to merge the most functional aspects of existing coding schemes. These findings will allow researchers and teachers to determine the characteristics of discipline-specific visuals that students most frequently encounter and to develop instructional strategies to support students' comprehension. Additionally, through these findings, we critique the extent to which current texts incorporate theoretical principles of visual design.

\section{Review of Relevant Literature}

Although originating in arts and arts education, visual literacy is now the nexus among the fields of arts education, cognitive psychology, literacy, and STEM (science, technology, engineering, and math) education (Baker, 2012). Not surprisingly, researchers do not agree on a single taxonomy, which limits teachers' capacity to instruct on visuals in a systematic manner. Despite variation, researchers have typically classified visuals by form (i.e., type), function, or quality. In this section, we examine the classification schemes informing this work. Next, we discuss the purpose of visuals in textbooks and explore research examining the efficacy of visuals in science and social studies. 


\section{Theories Underlying Use of Visuals in Instructional Materials}

Our classification scheme is grounded in three interrelated theoretical perspectives: dual coding theory (Sadoski \& Paivio, 2013), visual argument hypothesis (Larkin \& Simon, 1987), and the conjoint retention hypothesis (Kulhavy, Lee, \& Caterino, 1985). In a systematic review, Vekiri (2002) used these theories to explain the benefits of visuals for learning. All three theories are cognitivist and based on the information processing approach to learning, which assumes that working memory limits learning. Thus, these theories posit that adding visuals aids working memory by providing two routes (verbal and nonverbal) for readers to encode and retrieve information (Kulhavy et al., 1985; Sadoski \& Paivio, 2013) or by spatially chunking discrete information in groups, thus enhancing memory capacity (Larkin \& Simon, 1987). Consequently, the presence of visuals in text can enhance learning (Hannus \& Hyönä, 1999; Norman, 2010).

\section{What Are Major Types and Functions of Visuals?}

An effective system for categorizing the types of graphics must be specific enough to capture the unique forms of information presented while remaining broad enough to generalize use across situations. Researchers have struggled to strike such a balance. Vekiri (2002) summarized four common types of visuals, each with unique conventions for communication: diagrams, graphs, maps, and (network) charts. In contrast, Fingeret (2012) proposed eight types of visuals with 59 discrete subtypes. Although Fingeret's classification is highly comprehensive, lack of explicit discrimination between certain subtypes renders replication challenging. More recently, connected to Fingeret's work, Roberts and colleagues (2013) classified eight forms: captioned graphics, diagram, flowcharts, graphs, insets, maps, tables, and time lines. This work advanced the field by providing construct definitions and examples for each type.

Beyond form, researchers have also focused on visual function (e.g., Carney \& Levin, 2002; Concannon, 1975; Hegarty, Carpenter, \& Just, 1996; Levin, Anglin, \& Carney, 1987). The five functions established by Levin and colleagues (1987) are most prevalent: (a) decorative, $(b)$ representational, $(c)$ organizational, $(d)$ interpretational, and $(e)$ transformational. A decorative visual serves an ornamental purpose but does not meaningfully support the text (e.g., a cheetah photo on the cover of a biology text). Representational visuals show an aspect of the literal meaning (e.g., a photo of Ellis Island with text describing European immigration) and bring concreteness to abstract concepts (Sadoski \& Paivio, 2013). Organizational visuals categorize information in text (e.g., a table summarizing experimental data). This organizational function is indispensable within informational textbooks because students recall organized information better than discrete facts (Armbruster, Anderson, \& Meyer, 1991). Interpretational visuals contain elements of both representational and organizational functions but exceed them by presenting information in a manner that assists a reader's comprehension (e.g., an 1860 U.S. map with arrows detailing the troop movement). Transformational visuals primarily derive from mnemonics and attempt to recode information into a memorable form (e.g., an atom depicted in a shape of a pen to provide a mnemonic device for proton, electron, and neutron). More recently, researchers (e.g., Bishop \& Hickman, 1992; Fang, 1996; Nikolajeva \& Scott, 2000) 
added extensional visuals, which provide related information not explicitly included in the text (e.g., U.S. rail expansion book with diagrams of locomotives not actually discussed in the text).

\section{How Do Visuals Affect Learning?}

Despite sharing theoretical ground, existing research has differing conclusions regarding the efficacy of visuals in textbooks. Primarily quantitative, many aforementioned studies focus on students' reading outcomes after studying a visual, such as how a diagram facilitated comprehension. A recent meta-analytic study (Guo, Zhang, McTigue, \& Wright, 2017) revealed that the inclusion of visuals has an overall medium positive effect on students' reading comprehension, with an overall effect size of .49.

Yet the type of readers who benefit from visuals is less clear. Earlier work suggested that visuals differentially support low-achieving readers' comprehension (Hayes \& Reinking, 1991; Holmes, 1987), which led researchers to infer that the benefit of visuals derived from having information independent of decoding. For instance, Holmes (1987) revealed that although more skilled readers scored higher when processing text (alone), students in both groups performed better with an illustrated text. Other researchers challenged the conclusion that visuals benefited less skilled readers, demonstrating that visuals may be differentially beneficial for skilled readers (Hannus \& Hyönä, 1999; Harber, 1983; Reid \& Beveridge, 1986). Eye-movement studies have revealed a potential explanation: Jian (2016) found that children's capacity to integrate information in visuals is limited, possibly because of the cognitive cost of switching between two sources. However, skilled readers are strategic processors who focus on pertinent segments of visuals (Hannus \& Hyönä, 1999; Jian \& Ko, 2017). Such findings suggest that skilled readers develop more sophisticated strategies for managing multiple sources (Jian \& Ko, 2017).

\section{Discipline-Specific Use of Visuals}

Research has documented that there are significant differences in the vocabulary, syntax, and text structure across different disciplines (Shanahan \& Shanahan, 2012). Specifically, when compared with social studies texts, texts in science contain "many technical vocabularies and dense sentences that require readers to draw on multiple concepts simultaneously" (Fang \& Schleppegrell, 2010, p. 588). These unique patterns of language require students to rely on discipline-specific approaches to processing text (Fisher \& Frey, 2012), and that requirement has numerous implications for classroom instruction and teacher preparation.

Although the differences in graphics across disciplines have been less explored, disciplinary literacy findings lead us to infer that the types and functions of graphics would also differ markedly across disciplines. For example, Shanahan and Shanahan (2008) demonstrated the manner in which professional scientists attend to graphics while reading (i.e., the process) but provided no analysis of how historians or mathematicians approached visuals in their reading. Additionally, except for Fingeret (2012), researchers have not compared findings across disciplines. Fingeret quantified specific differences, namely, that the social studies textbooks contained a higher proportion 
of maps, whereas science textbooks had more diagrams. However, this study provides few conclusions regarding other types of graphics (e.g., picture, flow chart), visual density, or function differences, thus calling for further investigations.

\section{The Challenges of Reading Visuals in Textbooks}

Textbooks (and their visuals) in the United States have been critiqued as an artifact reflecting compromises from political, economic, and cultural interests rather than our most current pedagogical knowledge (e.g., Apple \& Christian-Smith, 1991). Given such complex influences, visuals are not selected through rigorous pilot testing, and the resulting texts put the interpretational burden on students (Roberts \& Brugar, 2014, 2017; Stylianidou, 2002). For instance, Roberts and Brugar (2014) found that more than $40 \%$ of third-grade students misunderstood the purpose of time lines in social studies texts. In science textbooks, Stylianidou (2002) found that students could not easily identify which graphical elements contained the most meaning. Moreover, many students did not perceive the intended message, particularly because they had problems integrating information from the text and the graphics (Stylianidou, 2002). These results call for systematic instructions for the "effective use of graphics, which is [a] multifaceted task - students should be able to read graphics, locate specific information within graphics, create graphics to organize information, [and] communicate to others through the use of graphics" (Coleman et al., 2011, p. 617). Without well-honed visual literacy skills, students are unlikely to employ graphics to their fullest potential.

Despite the need for specific instruction in reading visuals, U.S. teachers' instructions in this area are limited in both frequency and depth (Brugar \& Roberts, 2017; Coleman et al., 2011). When asked about their practices for assisting children in interpreting graphics, Coleman et al. (2011) found the most frequent instructional activity was pointing at graphics. However, according to Peeck (1993), although such instructional practice may help students attend to graphics, it does little to support visual comprehension skills. In contrast, instructional practices that would better scaffold students to develop visual processing skills (e.g., creating or comparing visuals) were rarely reported. For instance, a large proportion of teachers reported they never or rarely taught students to draw and label graphics ( $73 \%$ and $49 \%$, respectively), nor did they have students explain a graphic (35\%). Teachers' lack of preparation or attention to visual literacy is not specific to the United States; it is also documented in South Africa (Moodley, 2013) and Norway (Erstad, 2012). In contrast, in Australia, visual literacy has been part of the national curriculum for a decade and includes critical aspects of visual literacy (Callow, 2008), providing a model for other nations.

\section{Purpose and Research Questions}

The purpose of the current study is to evaluate the visuals in third- and fifth-grade science and social studies textbooks to better inform researchers and educators who are seeking to support students' visual literacy. As recommended by Pearson and Hiebert (2014), we developed and used a qualitative system for coding the visuals and describing how they may add to text complexity. Our research is guided by the fol- 
lowing questions: (1) What types of visuals are present in third- and fifth-grade science and social studies textbooks, and what are the semantic functions of those visuals? (2) Do the types and semantic functions of visuals differ in science and social studies textbooks? If so, how do they differ?

\section{Method}

\section{Definition of Visuals}

In this study, we analyzed visuals in informational texts, "whose primary purpose is to convey information about the natural, social, or physical world, and that has particular linguistic features to accomplish the goal" (Duke \& Billman, 2009, p. 110). Consistent with previous research (Norman, 2012), we defined visuals as graphical displays, which are not limited to diagrams, maps, graphs, and tables. A visual may contain some text, such as labels on a regional map, or a caption; however, the main source of information comes from visual, rather than textual, presentation. Not all visuals in textbooks meet this definition (Fingeret, 2012). For instance, Slough and colleagues (2010) found that approximately $33 \%$ of graphics were decorative. Whereas a border of leaves on a chapter about plants may be eye-catching, we did not consider it a visual display because it did not communicate information. Additionally, although textbook authors often provided a brief overview of the content formatted in a shaded box, it is the summary, not the visual organization, that adds to student learning. Therefore, we did not include these summaries.

\section{Textbook Sample}

This study focuses on the visuals in third and fifth graders' science and social studies textbooks. We selected textbooks because they are frequently encountered in $\mathrm{K}-12$ classrooms, whereas, historically, other types of informational texts are often limited (Duke, 2000; Palincsar \& Duke, 2004). Additionally, although researchers have examined the visuals in trade books (see Coleman \& Dantzler, 2016), questions remain regarding whether those trade books are present in classroom libraries (Wright, Hodges, \& Coleman, 2017).

In selecting textbooks, we began by identifying those adopted by highly populated states. This allowed us to assume that the textbooks would be present in many classrooms. Texas, for instance, is known for influencing textbook adoption nationwide because of its large population and subsequent buying power (Hiebert, 2005; Sadker, Zittleman, \& Sadker, 2012). Furthermore, these states' textbooks have been used to build representative samples in similar content analyses (see Harmon, Hedrick, \& Fox, 2000). In total, we included seven textbooks (see Table 1). To diversify our sample, we included textbooks adopted in states that both have (i.e., Florida and New York) and have not (i.e., Texas) implemented aspects of the Common Core.

We focused on upper elementary grades because at these grades, many children encounter their first standardized content exams. This testing emphasis suggests that it is critical to understand the cognitive demands of visuals for upper elementary students because they will be expected not only to comprehend their textbooks but also to derive content knowledge. 
Table 1. Textbook Sample

\begin{tabular}{|c|c|c|c|c|c|}
\hline \multirow[b]{3}{*}{ Subject } & \multirow[b]{3}{*}{ Series } & \multicolumn{4}{|c|}{ Adoption } \\
\hline & & \multicolumn{2}{|c|}{ Grade 3} & \multicolumn{2}{|c|}{ Grade 5} \\
\hline & & Texas & Common Core & Texas & Common Core \\
\hline \multirow[t]{2}{*}{ Science } & Science Fusion & $\sqrt{ }$ & - & $\sqrt{ }$ & - \\
\hline & Science Resources & $\sqrt{ }$ & $\sqrt{ }$ & $\sqrt{ }$ & $\sqrt{ }$ \\
\hline \multirow[t]{2}{*}{ Social studies } & myWorld & $\sqrt{ }$ & $\sqrt{ }$ & $\sqrt{ }$ & $\sqrt{ }$ \\
\hline & United States History & - & - & - & $\sqrt{ }$ \\
\hline
\end{tabular}

Our focus on science was influenced by national standards. Specifically, the Next Generation Science Standards (NGSS Lead States, 2013, p. 416) identified "developing and using models" as one of the habits of mind necessary to engage in scientific inquiry. Many scientific models include visual representations, and students need exposure to models before they can use and create them independently (NGSS Lead States, 2013). We included two series of science textbooks, Science Fusion (DiSpezio, Heithaus, \& Frank, 2014a, 2014b) and Science Resources (Lawrence Hall of Science, 2014a, 2014b). Both series include textbooks for grade 3 and grade 5 (four science textbooks total) and cover topics in life, physical, and earth sciences. At the time of our analysis, Science Fusion had been adopted by Texas, whereas Science Resources was used by both Texas and Common Core states. Each book covered 1 year's worth of lessons.

Our decision to also investigate social studies texts is based on recommendations from the National Council for Social Studies, which identified that the ability to gather and evaluate visual sources is an important part of the College, Career, and Civic Life Framework (National Council for the Social Studies, 2013). The social studies set of textbooks contained three separate texts. We examined two series of books: myWorld (Alonzo, Bennett, Kracht, \& White, 2016a, 2016b) and United States History (2013). At the time of this analysis, both Texas and Common Core states had adopted myWorld. To further diversify our social studies material, we also included a fifth-grade social studies textbook from Florida, United States History.

\section{Coding Scheme}

Following Fingeret (2012), we adopted the content/comparative approach for analysis (Strauss \& Corbin, 1998). After comparing categories of visual displays from several studies (e.g., Coleman \& Dantzler, 2016; Fingeret, 2012; Roberts et al., 2013), we created an exhaustive list (see Table A1). Next, we adapted the coding scheme from Fingeret to generate a list of detailed subtypes. For example, we identified diagrams as visuals displaying components of whole static relationships with labeled parts. Within diagrams, we identified seven subtypes, including bird's-eye view and cutaway diagrams. To further explicate, two authors independently drafted tentative definitions for each visual category and found representative examples. With the third author, we refined definitions (see Table A1 for the coding scheme).

We also developed a coding scheme to describe the visuals' functions. Initially, we coded visuals by their primary function (i.e., decorative, representative, organizational, interpretational, transformational; see Carney \& Levin, 2002). If a visual had 
several different functions (e.g., a simple diagram may be both representational and organizational), we coded the most prominent function determined by the surrounding text.

Fingeret (2012) coded any visuals that added new information as extensional, even if the primary function was representational. However, $64 \%$ of all visuals were extensional. To better capture and describe the functions, we coded extensions separately from graphical function. We coded the function of the graphic and then noted whether the visual added information distinct from the text. Modifying a scheme from Slough and McTigue (2013), we categorized these connections as either Level 1 or Level 2. We identified a visual as having a connection when it both represented the textual information and added new information. When reading a visual with a Level 1 connection, students would be able to easily interpret and connect the additional information to what they had read in the text. For instance, the caption may use slightly different verbiage, thus introducing new vocabulary while being explicitly tied to the text. However, a Level 2 connection would be more difficult to interpret, and the link between the text and the new information would require more inferencing. For example, in one science textbook, a passage introduced the concept of temperature, and the graphic presented ice in a glass with a caption asking the student to predict the water temperature. Engaging with this would require the student to have background knowledge about the properties of water in different phases.

\section{Coding Procedures}

To begin, the first and the second authors independently coded 100 pages of the same textbook. By comparing and discussing the results as a group, we clarified ambiguous items (e.g., the differences between cutaway and cross-section diagrams). Then, we generated examples and definitions for each visual type and subtype. Because our interest was in visuals that were intended to portray information, we only coded visuals in the content section of the textbooks. We excluded visuals in exercise sections (e.g., unit review exercises). However, within the main text, we coded when visuals asked children to complete a task, such as filling in a partially completed table. Such visuals were noted as interactive.

We treated captions as a part of visuals, and they were often critical to coding visual functions. For instance, if the visual and written text provided the same information but the caption added new details, the visual was coded as representational with a connection. For example, one social studies text introduced the establishment of Yellowstone National Park without mentioning the year it was established; however, this information was provided in the caption. We therefore coded the picture as a representational visual with Level 1 connection.

Next, we discussed and coded a subset of visuals. After the final consensus was reached, the first author independently coded the remaining textbooks. Items for which coding was uncertain were marked for further discussion. All authors met frequently to discuss progress and ambiguous visuals. This allowed the procedures to become increasingly more refined as the coding progressed.

To keep coding consistent, we did not expand our scheme until a new visual type appeared that demanded a different interpretative task for readers. We discussed these new types, and only after we reached consensus would we add a new type or a sub- 
type to the coding scheme. For instance, after discussion, coders decided to add comic strips as a unique type, as we found these visuals in multiple texts, providing instructions, entertainment, or examples.

When a single visual was composed of one visual type overlaid on another, we coded such visual as hybrid. We coded the visual by its primary type, defined by identifying the prominent features most likely to attract a student's attention. An example would be a time line of inventions, with attached photographs to the side, which we coded as a hybrid time line.

\section{Statistical Analysis}

Using IBM SPSS Statistics for Windows (Version 23) software, we computed the visual types and functions. To address our second research question, we performed a chi-square test of independence to examine whether visuals in social studies and science textbooks were statistically different. According to Thompson (1988), a chisquare test can depict the data only as a whole picture and fails to report an individual cell's contributions to a statistically significant chi-square result. Therefore, we conducted a pair-wise post hoc test, using the Gardner (2001) procedure, to determine how the visuals differed. The Gardner procedure tends to minimize Type I error rates, thus allowing us to compare specific cells for statistically significant differences (MacDonald \& Gardner, 2000).

\section{Results}

In total, we coded 3,844 visuals from seven textbooks. Visuals in science texts represent slightly more than $60 \%(n=2,324)$ of the sample. In the following sections, we describe the types of graphics in the combined sample and then provide the results of the chi-square analyses, allowing us to detail how science and social studies visuals differ in form and function.

\section{Types of Visuals}

The data showed nine major visual types and 54 distinct subtypes (see Table 2). Of those nine categories, photographs (62.4\%) were most prevalent. General images and maps were the second and third most represented, but the proportions of these two types were relatively small.

Although the total sample demonstrated a high frequency of photographs and general images, each discipline's textbooks contained different proportions. Table 3 lists the frequency and percentages of visual types in science and social studies textbooks and in the overall sample.

Results from chi-square tests showed that the types of visuals significantly differed between the two disciplines, $\chi^{2}(8, N=3,844)=647.165, p<.05$, with a medium effect size (Cramer's $V=.41$ ). Next, we conducted the post hoc analysis to determine which types demonstrated statistically significant differences. As suggested by Gardner (2001), we used a calculated $p$ value with an adjusted alpha level (MacDonald \& Gardner, 2000). Because there were 18 cells in the analysis, our alpha was set to $.05 / 18$, or .0028 . The results showed a significant difference between the relative 
Table 2. Frequency of Visual Categories and Types

\begin{tabular}{|c|c|c|c|}
\hline Visual Type & Frequency & $\%$ All Visual Types & \% Within Visual Types \\
\hline Total & 3,844 & 100 & \\
\hline Photographs: & 2,397 & 62.36 & 100 \\
\hline Simple & 2,220 & 57.75 & 92.62 \\
\hline Cluster & 177 & 4.60 & 7.38 \\
\hline General images: & 626 & 16.29 & 100 \\
\hline Fine art & 272 & 7.08 & 43.45 \\
\hline Cartoon illustration & 131 & 3.41 & 20.93 \\
\hline Computer-enhanced photograph & 78 & 2.03 & 12.46 \\
\hline Realistic illustration & 38 & .99 & 6.07 \\
\hline Cartoon/thought-bubble text box & 35 & .91 & 5.59 \\
\hline Image cluster & 29 & .75 & 4.63 \\
\hline Magnified & 16 & .42 & 2.56 \\
\hline Logo & 6 & .16 & .96 \\
\hline Scientific model & 6 & .16 & .96 \\
\hline Stop motion & 6 & .16 & .96 \\
\hline $\mathrm{X}$-rays & 4 & .10 & .64 \\
\hline Screenshot & 2 & .05 & .32 \\
\hline Photograph of illustrations & 2 & .05 & .32 \\
\hline Bird's-eye view & 1 & .03 & .16 \\
\hline Characters (foreign language) & o & .00 & .00 \\
\hline Radar & o & .00 & .00 \\
\hline Maps: & 203 & 5.28 & 100 \\
\hline Region & 91 & 2.37 & 44.83 \\
\hline Flow & 33 & .86 & 16.26 \\
\hline Context & 32 & .83 & 15.76 \\
\hline Topographic & 14 & .36 & 6.90 \\
\hline Grid & 12 & .31 & 5.91 \\
\hline Simple & 12 & .31 & 5.91 \\
\hline Cluster & 4 & .10 & 1.97 \\
\hline Cartoon & 2 & .05 & .99 \\
\hline Street & 2 & .05 & .99 \\
\hline Landmark & o & .00 & .00 \\
\hline Diagrams: & 173 & 4.50 & 100 \\
\hline Simple & 104 & 2.71 & 60.12 \\
\hline Cutaway & 19 & .49 & 10.98 \\
\hline Cross-section & 17 & .44 & 9.83 \\
\hline Scale, picture unit & 16 & .42 & 9.25 \\
\hline Scale, conventional unit & 10 & .26 & 5.78 \\
\hline Bird's-eye view & 4 & .10 & 2.31 \\
\hline Cutaway, cluster & 3 & .08 & 1.73 \\
\hline Illustrated equation & 1 & .03 & .58 \\
\hline Flow diagrams: & 173 & 4.50 & 100 \\
\hline Linear sequence & 97 & 2.52 & 56.07 \\
\hline Tree & 33 & .86 & 19.08 \\
\hline Flow with cyclical sequences & 26 & .68 & 15.03 \\
\hline Web & 11 & .29 & 6.36 \\
\hline Flow with forked sequences & 6 & .16 & 3.47 \\
\hline Tables: & 149 & 3.88 & 100 \\
\hline Column & 65 & 1.69 & 43.62 \\
\hline Row and column & 59 & 1.53 & 39.60 \\
\hline Row & 14 & .36 & 9.40 \\
\hline Pictorial & 11 & .29 & 7.38 \\
\hline Graphs: & 71 & 1.85 & 100 \\
\hline Venn diagram & 22 & .57 & 30.99 \\
\hline Line & 18 & .47 & 25.35 \\
\hline Bar & 15 & .39 & 21.13 \\
\hline Pie chart & 10 & .26 & 14.08 \\
\hline Pyramid chart & 6 & .16 & 8.45 \\
\hline
\end{tabular}


Table 2. (Continued)

\begin{tabular}{lccc}
\hline Visual Type & Frequency & \% All Visual Types & \% Within Visual Types \\
\hline Time lines: & 29 & .75 & 100 \\
Simple & 28 & .73 & 96.55 \\
Multiple & 1 & .03 & 3.45 \\
Comic strips: & 23 & .60 & 100 \\
Produced to provide instruction & 18 & .47 & 78.26 \\
Provide entertainment or examples & 5 & .13 & 21.74 \\
Elements: & 350 & 100 & - \\
Inset & 122 & 35 & \\
Key & 122 & 35 & \\
Hybrid & 106 & 30 & \\
\hline
\end{tabular}

proportions of visuals in science and social studies textbooks associated with diagrams, graphs, time lines, maps, tables, general images, photographs, and comic strips $(p<.0028$; see Table 4$)$. Science textbooks were more likely to contain diagrams and photographs. By contrast, social studies texts had a higher proportion of graphs, time lines, maps, tables, general images, and comic strips, indicating a larger variety of graphics. Interestingly, there was no difference in the proportion of flow diagrams.

Considering complexity, there were 350 instances of additional elements (i.e., insets, keys, or hybrids; see Table 5). Because some visuals contained multiple elements, these data were not orthogonal and thus did not meet the assumptions necessary for a chi-square test (McHugh, 2013). However, science textbooks had a higher percentage of hybrid visuals and insets, whereas those used in social studies contained a higher percentage of keys.

\section{Functions of Visuals}

As detailed in Table 6, a majority of the visuals (60.9\%) served a representational function (i.e., reflected information from the main text). Additionally, there were no transformational visuals and very few decorative visuals.

The chi-square test demonstrated a significant difference associated with functions, $\chi^{2}(3, N=3,844)=69.864, p<.001$, with a small effect size (Cramer's $\left.V=.135\right)$. We again adjusted our alpha levels for the post hoc test, in this case dividing the standard .05 by 8 to yield $p<.0063$. When examining each function, we found that the

Table 3. Frequency (Percentage) of Visual Subtypes

\begin{tabular}{lccc}
\hline Visual Type & Science & Social Studies & Both \\
\hline Total & 2,324 & 1,520 & 3,844 \\
Photographs & $1,724(74.2)$ & $673(44.3)$ & $2,397(62.4)$ \\
General images & $206(8.9)$ & $420(27.6)$ & $626(16.3)$ \\
Maps & $31(1.3)$ & $172(11.3)$ & $203(5.3)$ \\
Diagrams & $159(6.8)$ & $14(.9)$ & $173(4.5)$ \\
Flow diagrams & $104(4.5)$ & $69(4.5)$ & $173(4.5)$ \\
Tables & $64(2.8)$ & $85(5.6)$ & $149(3.9)$ \\
Graphs & $25(1.1)$ & $46(3.0)$ & $71(1.8)$ \\
Time lines & $6(.3)$ & $23(1.5)$ & $29(.8)$ \\
Comic strips & $5(.2)$ & $18(1.2)$ & $23(.6)$ \\
\hline
\end{tabular}

Note.- $\chi^{2}(8, N=3,844)=647.165, p<.05$, Cramer's $V=.410$ 
Table 4. Visual Category Post Hoc Analysis Results

\begin{tabular}{|c|c|c|c|}
\hline & Science & Social Studies & Total \\
\hline \multicolumn{4}{|l|}{ Photographs: } \\
\hline Count & 1,724 & 673 & 2,397 \\
\hline Expected count & $1,449.2$ & 947.8 & $2,397.0$ \\
\hline$\%$ within subject & 74.2 & 44.3 & 62.4 \\
\hline Adjusted residual & 18.7 & -18.7 & \\
\hline$p$ value & .0000 & .0000 & \\
\hline \multicolumn{4}{|l|}{ General images: } \\
\hline Count & 206 & 420 & 626 \\
\hline Expected count & 378.5 & 247.5 & 626.0 \\
\hline$\%$ within subject & 8.9 & 27.6 & 16.3 \\
\hline Adjusted residual & -15.4 & 15.4 & \\
\hline$p$ value & .0000 & .0000 & \\
\hline \multicolumn{4}{|l|}{ Maps: } \\
\hline Count & 31 & 172 & 203 \\
\hline Expected count & 122.7 & 80.3 & 203.0 \\
\hline$\%$ within subject & 1.3 & 11.3 & .8 \\
\hline Adjusted residual & -13.5 & 13.5 & \\
\hline$p$ value & .0000 & .0000 & \\
\hline \multicolumn{4}{|l|}{ Diagrams: } \\
\hline Count & 159 & 14 & 173 \\
\hline Expected count & 104.6 & 68.4 & 173.0 \\
\hline$\%$ within subject & 6.8 & .09 & 4.5 \\
\hline Adjusted residual & 8.7 & -8.7 & \\
\hline$p$ value & .0000 & .0000 & \\
\hline \multicolumn{4}{|l|}{ Flow diagrams: } \\
\hline Count & 104 & 69 & 173 \\
\hline Expected count & 104.6 & 68.4 & 173.0 \\
\hline$\%$ within subject & 4.5 & 4.5 & 4.5 \\
\hline Adjusted residual & -.1 & .1 & \\
\hline$p$ value & .9203 & .9203 & \\
\hline \multicolumn{4}{|l|}{ Tables: } \\
\hline Count & 64 & 85 & 149 \\
\hline Expected count & 9.1 & 58.9 & 149.0 \\
\hline$\%$ within subject & 2.8 & 5.6 & 3.9 \\
\hline Adjusted residual & -4.5 & 4.5 & \\
\hline$p$ value & .00001 & .00001 & \\
\hline \multicolumn{4}{|l|}{ Graphs: } \\
\hline Count & 25 & 46 & 71 \\
\hline Expected count & 42.9 & 28.1 & 71.0 \\
\hline$\%$ within subject & 1.1 & 3.0 & 1.8 \\
\hline Adjusted residual & -4.4 & 4.4 & \\
\hline$p$ value & .00001 & .00001 & \\
\hline \multicolumn{4}{|l|}{ Time lines: } \\
\hline Count & 6 & 23 & 29 \\
\hline Expected count & 17.5 & 11.5 & 29.0 \\
\hline$\%$ within subject & 3 & 1.5 & .8 \\
\hline Adjusted residual & -4.4 & 4.4 & \\
\hline$p$ value & .00001 & .00001 & \\
\hline \multicolumn{4}{|l|}{ Comic strips: } \\
\hline Count & 5 & 18 & 23 \\
\hline Expected count & 13.9 & 9.1 & 23.0 \\
\hline$\%$ within subject & .2 & 1.2 & .6 \\
\hline Adjusted residual & -3.8 & 3.8 & \\
\hline$p$ value & .00015 & .00015 & \\
\hline
\end{tabular}


Table 5. Frequency (Percentage) of Elements in Textbooks

\begin{tabular}{lccc}
\hline Element & Science & Social Studies & Both \\
\hline Total & 163 & 187 & 350 \\
Insets & $86(52.8)$ & $36(19.3)$ & $122(34.9)$ \\
Keys & $9(5.5)$ & $113(60.4)$ & $122(34.9)$ \\
Hybrids & $68(41.7)$ & $38(20.3)$ & $106(30.2)$ \\
\hline
\end{tabular}

proportion of representative visuals differed significantly (see Table 7). Moreover, pair-wise tests demonstrated that the proportions of representational and organizational visuals differed significantly $(p<.0063)$. Social studies textbooks contained a relatively larger proportion of organizational visuals, whereas science texts contained a larger proportion of representational visuals. The proportions of interpretational and decorative visuals were not significantly different.

Finally, we analyzed connection visuals. In total, 1,615 (42.01\%) of the visuals contained new information. Among them, $73.4 \%$ provided information clearly linked to the text, which would be easy for students to interpret (see Table 8 ). The remainder (26.6\%) were Level 2 and provided new information not concretely linked to the text.

The findings indicated that the proportions of Level 1 and Level 2 visuals in the science textbooks differed significantly from those in social studies, $\chi^{2}(1, N=1,615)=$ $22.771, p<.001$, with a small effect size of .119. Social studies textbooks contained relatively more Level 2 visuals (see Table 9), whereas science textbooks had more Level 1 visuals.

\section{Discussion}

Before strategically preparing students to navigate the visual complexity of informational texts, we need to understand modern academic texts. Additionally, as our understanding of disciplinary literacy becomes more comprehensive, we must consider the visual demands and conventions of graphics in each discipline. Therefore, we aimed to investigate the types and functions of visuals in U.S. third- and fifth-grade science and social studies textbooks. The results regarding the most common types and functions of visuals were consistent with the findings of Fingeret (2012), indicating that aspects of text design may be stable, despite changes in publication technology. Most notably, across both studies, photographs and general images (e.g., drawings, cartoons) were most common. In addition, the majority of the visuals were

Table 6. Frequency (Percentage) of Visual Functions

\begin{tabular}{lccc}
\hline Function & Science & Social Studies & Both \\
\hline Total & 2,324 & 1,520 & 3,844 \\
Representational & $1,490(64.1)$ & $850(55.9)$ & $2,340(60.9)$ \\
Interpretational & $486(20.9)$ & $292(19.2)$ & $778(20.2)$ \\
Organizational & $295(12.7)$ & $349(23.0)$ & $644(16.8)$ \\
Decorative & $53(2.3)$ & $29(1.9)$ & $82(2.1)$ \\
Transformational & $\mathrm{o}(0)$ & $\mathrm{o}(0)$ & $0(0)$ \\
\hline
\end{tabular}

Note. $-\chi^{2}(3, N=3,844)=69.864, p<.001$, Cramer's $V=.135$. As there were no transformational visuals, the degrees of freedom were reduced to 3 . 
Table 7. Visual Functions Post Hoc Analysis Results

\begin{tabular}{lccc}
\hline & Science & Social Studies & Total \\
\hline Representational: & & & \\
Count & 1,490 & 850 & 2,340 \\
Expected count & $1,414.7$ & 925.3 & $2,340.0$ \\
\% within subject & 64.1 & 55.9 & 60.9 \\
Adjusted residual & 5.1 & -5.1 & \\
$p$ value & .000 & .000 & \\
Interpretational: & & & 778 \\
Count & 486 & 292 & 778.0 \\
Expected count & 470.4 & 307.6 & \\
\% within subject & 20.9 & 19.2 & 644 \\
Adjusted residual & 1.3 & -1.3 & 644.0 \\
$p$ value & .197 & .197 & 16.8 \\
Organizational: & & & \\
Count & 295 & 349 & 82 \\
Expected count & 389.3 & 254.7 & 2.1 \\
\% within subject & 12.7 & 23.0 & \\
Adjusted residual & -8.3 & 8.3 & \\
$p$ value & .000 & .000 & \\
Decorative: & & & \\
Count & 53 & 32.4 & \\
Expected count & 49.6 & -.8 & \\
\% within subject & 2.3 & .424 & \\
Adjusted residual & .824 & & \\
$p$ value & & & \\
\hline
\end{tabular}

representational in function - they concretely depicted the text information. In addition, our revised coding revealed notable findings regarding types and functions. In the following section, we present main findings organized by research question. Next, we examine differences between the two disciplines. Finally, we discuss implications and future research directions.

\section{Types and Semantic Functions of Visuals}

Types. To answer our first research question, we examined the visual frequencies. We found that photographs and general images are the most common visuals (62.4\% and $16.3 \%$, respectively). Interestingly, despite their prominence, photographs were not included in Vekiri's (2002) or Roberts and colleague's (2013) work-photographs were embedded within a more generic category of captioned graphics. Therefore, photographs may have received relatively limited attention, perhaps because the (false) assumption of objectivity and interpretation ease. Although photographs have long been associated with documentation of fact (Walden, 2012), social critics (e.g.,

Table 8. Frequency (Percentage) of Connection Visuals

\begin{tabular}{lccc}
\hline Connection & Science & Social Studies & Both \\
\hline Total & 775 & 840 & 1,615 \\
Level 1 & $611(78.8)$ & $574(68.3)$ & $1,185(73.4)$ \\
Level 2 & $164(21.2)$ & $266(31.7)$ & $430(26.6)$ \\
\hline
\end{tabular}

\footnotetext{
Note. $-\chi^{2}(1, N=1,615)=22.771, p<.001$, Cramer's $V=.119$.
} 
Table 9. Visual Connections Analysis Results

\begin{tabular}{lccc}
\hline & Science & Social Studies & Total \\
\hline Level 1: & & & \\
$\quad$ Count & 611 & 574 & 1,185 \\
Expected count & 568.7 & 616.3 & $1,185.0$ \\
\% within subject & 78.8 & 68.3 & 73.4 \\
Level 2: & & & \\
$\quad$ Count & 164 & 266 & 430 \\
Expected count & 206.3 & 223.7 & 430.0 \\
\% within subject & 21.2 & 31.7 & 26.6 \\
\hline
\end{tabular}

Sontag, 1977) and journalists (Bissell, 2000) have challenged the assumption of objectivity by highlighting the role of the photographer and other gatekeepers (e.g., editors) who may modify images. However, as outlined in Callow's (2008) framework, young learners can be taught to assess visual features when viewing a photograph, as well as the metalanguage to describe the shot distance, angle, and character gaze. Particularly relevant for history texts, in the same manner that readers benefit from being taught to evaluate the sources used and the potential bias of the author (Shanahan \& Shanahan, 2008), children should be taught to scrutinize photographs with a critical eye.

Visual complexity. It is also important to note the growing variety of subtypes within photographs, likely resulting from technological growth in digital photography and adding challenges of interpretation. Beyond simple photographs, we documented photo clusters, photo hybrids, and photographs with cutaways. Whereas a simple photograph may be cognitively accessible for a young reader, a photo with a cutaway becomes complex. For example, one image presented a cutaway diagram of the heart, embedded in a photograph of a child's body. This visual display is informative because it illustrates the heart's internal structure and location within the body. However, the multilayered composition requires students to discern and attend to different forms. According to Gerber, Boulton-Lewis, and Bruce (1995), younger readers tend to fixate on isolated components when processing graphics. Without sophisticated strategies, they often struggled with processing and integrating information from multiple sources (McTigue \& Flowers, 2011). When both the density and intricacy of visuals increase, young learners may experience cognitive overload, leading them to simply ignore the visuals.

Semantic function. Most of these graphics served as representations (60.9\%), meaning they provided a concrete example to support the text. According to dual coding theory (Clark \& Paivio, 1991), linking abstract concepts to concrete examples may help students comprehend, retain, and recall newly learned information. However, we do not mean to imply that representational visuals are simply redundant with the text-more than $40 \%$ of the visuals coded added new information. Therefore, students should be encouraged to attend to visuals and extract information not available in the text. According to the cognitive theory of multimedia learning (Mayer, 2002), higher quality visuals both reinforce and extend the reader's knowledge. Unfortunately, previous work (e.g., Jian \& Ko, 2017; McTigue \& Flowers, 2011) indicates that students may not be fully attending to the graphics and risk missing key information from the text. This also has implications for assessment because many 
high-stakes tests require students to interpret visual information. In a review of state science tests, $79.5 \%$ of items could not be answered correctly without examining the graphics (Yeh \& McTigue, 2009).

Moreover, previous research indicated that the most advantageous graphics would be interpretational and transformational, as they would help the reader encode content in concrete and novel ways (Atkinson et al., 1999; Carney \& Levin, 2002). Unfortunately, we did not find any transformational graphics in these textbooks. Our result may indicate a gap between research and text design. On a positive note, we coded the majority of visuals that added new information (73.4\%) at the lowest level of connection, implying an explicit link between information in the visual and the text. Future research is needed to justify the implications of this finding, but it might indicate that the visual information would be relatively simple for young readers to integrate with the text. This finding is positive for the intended audience, as younger students have demonstrated difficulty perceiving the connections between information in two mediums (Jian, 2016).

\section{Differences between Disciplines}

Answering our second research question yielded interesting patterns. On average, science textbooks contained more diagrams and photographs than did social studies, with graphics most often serving a representational function. This finding is consistent with Fingeret's (2012) observations. When comparing our science textbook results with those of Coleman and Dantzler (2016), we see that both science trade books and textbooks contain high proportions of diagrams compared with other disciplines. These findings are expected because science often describes systems that are too small (e.g., microbiology) or too large (e.g., plate tectonics) to easily visualize or capture in a single photograph. Visual representations can help readers link the abstract process to a concrete example. Moreover, scientists self-report that they seek different representations of an idea while reading (Shanahan \& Shanahan, 2008). For example, one chemist demonstrated a systematic back-and-forth reading process between the text and the picture in an effort to relate the two sources of information. To such scientists, the visuals were essential to communicating a concept. This finding may indicate that science textbooks for children are adhering to disciplinary expectations.

By contrast, social studies textbooks contained a greater diversity of visual forms. Because such texts incorporate "any of the specific disciplines that fall within social studies - history, geography, civics and government, economics, psychology, sociology, and anthropology" (Myers et al., 2002, p. 17), it is reasonable that the visuals should be similarly diverse. Additionally, social studies textbooks were more likely to contain organizational or interpretational visuals. These form and function outcomes are connected because tables and maps generally add to the organization of information.

Nevertheless, this variety presents challenges because different skills are needed for interpretation. For example, students need specific skills to navigate maps (Brugar \& K. L. Roberts, 2014), time lines (Brugar \& K. Roberts, 2014), and tables (Brugar \& Roberts, 2015) in social studies. Roberts and Brugar (2014, p. 162) conclude that reading visuals in social studies texts "does not seem to be something that children are 
likely to be able to do in the absence of carefully planned, intentional instruction." Therefore, the variety of visuals in social studies texts will likely challenge students' comprehension, and teachers need to model effective comprehension strategies.

\section{Diversity within Science Textbooks}

Although the study's purpose was to capture general trends in the use of visuals within modern textbooks, our work also revealed qualitative differences between the two science textbook series. The visuals in Science Fusion tended to be complex and to include many hybrid visuals, such as cutaway diagrams embedded in a photo or time lines combined with photos. In contrast, the social studies series used graphics in a more consistent manner, which may reflect disciplinary expectations. Therefore, it is should be acknowledged that publishers are making unique decisions regarding visual use.

Moreover, many visuals in Science Fusion required student interactions. For instance, this textbook frequently cued students to fill in the blanks on diagrams. Such an interactive design has not been noted in earlier research and is more typical of supplemental workbooks than textbooks. Thus, Science Fusions contains more interpretative as well as connection visuals, which might work to engage students. It is unclear, however, whether such a design would be helpful because textbook interactions may be limited. Pragmatically, schools reuse textbooks over several years and thus do not encourage students to write in them. However, with the increased use of digital texts, perhaps these sorts of activities will become more common.

\section{Implications and Directions for Future Research}

Our work has implications for future research in the fields of visual and disciplinary literacy. These findings can focus visual literacy instruction in elementary classrooms on the most common visual types. Without explicit instruction, students are unlikely to deepen their understanding of multimodal text (Peeck, 1993). Additionally, the increased use of composition with layers of images requires attention to help students navigate such complex forms.

As mentioned previously, although most elementary teachers use graphics in daily instruction, they rarely teach how to interpret or produce visuals (Coleman et al., 2011). Thus, instructional approaches for visual literacy should be included in teacher preparation and professional development (Metros, 2008). Drawing from established frameworks (see Callow, 2008), teachers can integrate visual literacy into authentic learning experiences. Students need to be made aware that visuals often are not redundant but contain information that may not be in the text. Modeling and instruction in these areas will most likely differentially benefit less skilled readers, who often do not develop sophisticated strategies on their own (Jian \& Ko, 2017).

In addition to these general principles, students need discipline-specific instruction regarding how to read visuals in different genres. Roberts and Brugar (2017) recently explored students' understanding of four types of graphics in social studies textbooks. None of the students understood all aspects of these graphical devices, although there was a great variation across grades. For instance, while children often used maps outside of school, the purposes of maps in textbooks often differed from 
those experienced in daily life. Students could "use this knowledge as a bridge to understand [the] more abstract purpose of using maps in textbooks" (Roberts \& Brugar, 2017, p. 762), but proper application of background knowledge requires specific instruction and scaffolding. Because their study focused on four types of graphics, it would be valuable to extend this work to other common types of visuals. Our study documents the types of visuals that students will most often encounter in science and social studies textbooks, providing direction for future research.

Although convergent research suggests that graphical comprehension affects students' reading comprehension (Hannus \& Hyönä, 1999; Mayer \& Gallini, 1990; Roberts et al., 2015), a research gap is that few studies consider students' learning from authentic texts. Most research uses one graphic accompanying a block of text. Our work reveals a growing complexity of visual displays and layouts, suggesting that future studies should examine how young learners approach such layouts. Furthermore, studies describing how visual complexity increases across grade levels (in both textbooks and trade books) will be especially important in understanding the scaffolding that students need to comprehend graphics as they advance through the grades.

Further research is also needed to understand the utility of captions. Roberts and Brugar's (2017) study demonstrated that only $12.35 \%$ of elementary students could accurately or correctly name captions. When asked to create a caption, almost $20 \%$ of third-grade students misunderstood what a caption looks like. Overlooking captions is particularly concerning with more modern texts, such as the Science Fusion text, with extended captions blurring the line between adjunct visuals and the main text.

Finally, although we did not analyze e-books or examine electronic, particularly interactive, visuals that students encounter during online reading, the impact of this medium should be considered in future research. Mangen, Walgermo, and Brønnick (2013) found students had better comprehension after reading texts on paper than on computer screens. One explanation they offered is directly relevant for visuals, noting that "the fixity of text printed on paper supports reader's construction of the spatial representation of the text by providing unequivocal and fixed spatial cues for text memory and recall" (p. 66). Future investigations should extend this research to the visuals in computer-based informational texts.

\section{Limitations}

We collected a textbook sample that was purposeful and diverse, but it is not a random sampling. Likewise, although we chose textbooks on state-wide adoption lists, we do not know how many schools actually chose to invest in these texts. Additionally, although our coding scheme and procedures were based on previous research, we made modifications to better represent the visuals present in contemporary textbooks. We engaged in extensive collaboration to ensure reliability; however, future research will be required to fully validate this coding scheme. 


\section{Conclusion}

This study provides researchers and teachers with an overview of the types and functions of visuals in contemporary science and social studies textbooks. Overall, we found nine major types and 54 subtypes of visuals, indicating that students frequently encounter a diverse range of visuals. The categories and functions of visuals differed in science and social studies. This finding leads us to the conclusion that visual literacy is not a generic approach but a set of discipline-specific skills. Additionally, current texts rely heavily on visuals and incorporate complex visual presentations that students may not be prepared to navigate. To support students' comprehension of informational texts and retention of discipline-specific content, researchers should develop instructional strategies that will develop students' visual literacy skills.

\section{Appendix}

Table A1. Full Graphical Type Coding Scheme and Definitions

\begin{tabular}{|c|c|c|c|}
\hline Type & Description & Subtype & Definition \\
\hline \multirow[t]{2}{*}{ Comic strips } & \multirow[t]{2}{*}{$\begin{array}{l}\text { Traditional comic strips, } \\
\text { coded frame by frame }\end{array}$} & Provide content & $\begin{array}{l}\text { Typically produced by the } \\
\text { textbook authors or } \\
\text { publishers specifically } \\
\text { for the textbook }\end{array}$ \\
\hline & & $\begin{array}{c}\text { Provident entertainment/ } \\
\text { examples }\end{array}$ & $\begin{array}{l}\text { Typically produced else- } \\
\text { where (e.g., newspapers) } \\
\text { and reprinted in text }\end{array}$ \\
\hline \multirow[t]{7}{*}{ Diagrams } & \multirow{7}{*}{$\begin{array}{l}\text { Graphics that model either } \\
\text { the pieces or components } \\
\text { of a whole system or static } \\
\text { relationships between } \\
\text { parts; generally includes } \\
\text { labels }\end{array}$} & Bird's-eye view diagram & $\begin{array}{l}\text { Shows organization from } \\
\text { a top-down view }\end{array}$ \\
\hline & & Cutaway diagram & $\begin{array}{l}\text { A 3-D picture where pieces } \\
\text { are removed to make } \\
\text { internal features visible }\end{array}$ \\
\hline & & Cross-section & $\begin{array}{l}\text { Diagrams that include } \\
\text { normally unseen or } \\
\text { internal portions of an } \\
\text { object or scene }\end{array}$ \\
\hline & & Illustrated equation & $\begin{array}{l}\text { Mathematical or scientific } \\
\text { formulas displayed } \\
\text { visually }\end{array}$ \\
\hline & & $\begin{array}{l}\text { Scale diagram } \\
\text { (conventional) }\end{array}$ & $\begin{array}{l}\text { Diagrams showing the size } \\
\text { of something with a } \\
\text { conventional unit of } \\
\text { measurement for } \\
\text { reference }\end{array}$ \\
\hline & & Simple diagram & $\begin{array}{l}\text { Diagrams that do not } \\
\text { feature any of the other } \\
\text { defined characteristics }\end{array}$ \\
\hline & & Scale diagram (picture) & $\begin{array}{l}\text { Diagrams showing the } \\
\text { size of something in } \\
\text { comparison with other } \\
\text { visual information }\end{array}$ \\
\hline \multirow[t]{2}{*}{ Flow diagrams } & \multirow[t]{2}{*}{$\begin{array}{l}\text { Diagrams that model move- } \\
\text { ment, change, or complex } \\
\text { or hierarchical relation- } \\
\text { ships; generally uses arrows } \\
\text { to connect pictures or text }\end{array}$} & Cyclical sequences & $\begin{array}{l}\text { Flow diagram that may } \\
\text { or may not have a clear } \\
\text { start, but circles back } \\
\text { to the beginning }\end{array}$ \\
\hline & & Forked sequences & $\begin{array}{l}\text { Flow diagram with an } \\
\text { "either-or" choice within }\end{array}$ \\
\hline
\end{tabular}


Table A1. (Continued)

\begin{tabular}{|c|c|c|c|}
\hline Type & Description & Subtype & Definition \\
\hline & & & $\begin{array}{l}\text { the diagram. Not neces- } \\
\text { sarily hierarchical }\end{array}$ \\
\hline & & Linear sequence & $\begin{array}{l}\text { Flow diagram with clear } \\
\text { start and end point }\end{array}$ \\
\hline & & Tree diagram & $\begin{array}{l}\text { Flow diagram modeling } \\
\text { hierarchical relation- } \\
\text { ships or organization }\end{array}$ \\
\hline & & Web diagram & $\begin{array}{l}\text { Flow diagram modeling } \\
\text { multiple, intertwined } \\
\text { relationships. }\end{array}$ \\
\hline \multirow[t]{16}{*}{ General images } & $\begin{array}{l}\text { Information of all kinds, } \\
\text { sometimes symbolic, that }\end{array}$ & Bird's-eye view & $\begin{array}{l}\text { Shows image from a } \\
\text { top-down view }\end{array}$ \\
\hline & $\begin{array}{l}\text { require interpretation } \\
\text { by the reader and may }\end{array}$ & Cartoon illustrations & $\begin{array}{l}\text { A simplified or exaggerated } \\
\text { drawing of something }\end{array}$ \\
\hline & $\begin{array}{l}\text { require the use of back- } \\
\text { ground knowledge; does } \\
\text { not have lines with labels } \\
\text { or words (as is common }\end{array}$ & $\begin{array}{c}\text { Cartoon/thought-bubble } \\
\text { text }\end{array}$ & $\begin{array}{l}\text { Image of text that is stylized } \\
\text { to look like a cartoon. } \\
\text { Not embedded as part } \\
\text { of a comic strip }\end{array}$ \\
\hline & in diagrams) & Characters & $\begin{array}{l}\text { Images of foreign language } \\
\text { writing systems }\end{array}$ \\
\hline & & Computer-enhanced image & $\begin{array}{l}\text { Image with something } \\
\text { added by computer, such } \\
\text { as infrared mapping }\end{array}$ \\
\hline & & Fine art & $\begin{array}{l}\text { Images of professional or } \\
\text { historical art }\end{array}$ \\
\hline & & Image cluster & $\begin{array}{l}\text { Multiple images used as } \\
\text { part of one graphic }\end{array}$ \\
\hline & & Logo & $\begin{array}{l}\text { An image that represents a } \\
\text { company or organization }\end{array}$ \\
\hline & & Magnified image & $\begin{array}{l}\text { An image of something } \\
\text { that cannot be seen with } \\
\text { the naked eye }\end{array}$ \\
\hline & & Photographs of illustrations & $\begin{array}{l}\text { Photographic images of } \\
\text { previously produced } \\
\text { illustrations }\end{array}$ \\
\hline & & Radar image & $\begin{array}{l}\text { Image produced using } \\
\text { radar technology }\end{array}$ \\
\hline & & Realistic illustration & $\begin{array}{l}\text { A drawing of the content } \\
\text { that is realistic }\end{array}$ \\
\hline & & Scientific model & $\begin{array}{l}\text { Image of a model used to } \\
\text { illustrate a scientific } \\
\text { concept }\end{array}$ \\
\hline & & Screen shot & $\begin{array}{l}\text { Image created from the } \\
\text { screen of a computer }\end{array}$ \\
\hline & & Stop motion & $\begin{array}{l}\text { Series of images of the same } \\
\text { object at different points } \\
\text { in time }\end{array}$ \\
\hline & & $\mathrm{X}$-rays & $\begin{array}{l}\text { Images produced using } \\
\text { X-ray technology to see } \\
\text { inside of something (e.g., } \\
\text { bones) }\end{array}$ \\
\hline \multirow[t]{2}{*}{ Graphs } & $\begin{array}{l}\text { Visually organize qualities } \\
\text { or numbers }\end{array}$ & Bar graph & $\begin{array}{l}\text { Graph in which values are } \\
\text { represented by height } \\
\text { or length of lines }\end{array}$ \\
\hline & & Line graph & $\begin{array}{l}\text { Graph that uses line seg- } \\
\text { ments connected to data } \\
\text { points to show data over } \\
\text { time }\end{array}$ \\
\hline
\end{tabular}


Table A1. (Continued)

\begin{tabular}{|c|c|c|c|}
\hline Type & Description & Subtype & Definition \\
\hline & & Pie chart & $\begin{array}{l}\text { Circular shaped graph } \\
\text { divided into sectors } \\
\text { representing portions of } \\
\text { a whole }\end{array}$ \\
\hline & & Pyramid chart & $\begin{array}{l}\text { Chart in the form of a } \\
\text { triangle, divided into } \\
\text { sections, indicating a } \\
\text { hierarchy. }\end{array}$ \\
\hline & & Venn diagram & $\begin{array}{l}\text { Illustrates a relationship } \\
\text { between sets, usually } \\
\text { with a piece in common } \\
\text { where the sets overlap }\end{array}$ \\
\hline \multirow[t]{10}{*}{ Maps } & \multirow{10}{*}{$\begin{array}{l}\text { Geographical, sociological, } \\
\text { or scientific information } \\
\text { displayed on a represen- } \\
\text { tation of an area }\end{array}$} & Cartoon map & $\begin{array}{l}\text { Unrealistic but visually } \\
\text { appealing, map }\end{array}$ \\
\hline & & Context map & $\begin{array}{l}\text { Political or geographical } \\
\text { map of a region that } \\
\text { serves to provide context } \\
\text { for the information in } \\
\text { the text }\end{array}$ \\
\hline & & Flow map & $\begin{array}{l}\text { Map with arrows showing } \\
\text { movement or relation- } \\
\text { ships }\end{array}$ \\
\hline & & Grid map & $\begin{array}{l}\text { Map with a grid overlay to } \\
\text { define sections }\end{array}$ \\
\hline & & Landmark map & $\begin{array}{l}\text { Map that primarily features } \\
\text { the locations of specific } \\
\text { landmarks }\end{array}$ \\
\hline & & Map cluster & $\begin{array}{l}\text { Multiple maps used in } \\
\text { one graphic }\end{array}$ \\
\hline & & Region map & $\begin{array}{l}\text { Map of a larger area that } \\
\text { defines specific regions }\end{array}$ \\
\hline & & Simple map & $\begin{array}{l}\text { Map without any of the } \\
\text { other defined character- } \\
\text { istics }\end{array}$ \\
\hline & & Street map & $\begin{array}{l}\text { Map focused on the names } \\
\text { and locations of streets }\end{array}$ \\
\hline & & Topographical map & $\begin{array}{l}\text { Map displaying the eleva- } \\
\text { tion of an area }\end{array}$ \\
\hline \multirow[t]{2}{*}{ Photographs } & \multirow{2}{*}{$\begin{array}{l}\text { Photographs that do not fit } \\
\text { the description of images } \\
\text { or diagrams }\end{array}$} & Photo cluster & $\begin{array}{l}\text { Multiple photographs used } \\
\text { as part of one graphic }\end{array}$ \\
\hline & & Simple photographs & One photograph \\
\hline \multirow[t]{2}{*}{ Tables } & \multirow[t]{2}{*}{$\begin{array}{l}\text { Information organized } \\
\text { in rows and columns }\end{array}$} & $\begin{array}{l}\text { Column table } \\
\text { Pictorial table }\end{array}$ & $\begin{array}{l}\text { Table with a single column } \\
\text { Table that uses pictures to } \\
\text { display information }\end{array}$ \\
\hline & & $\begin{array}{c}\text { Row table } \\
\text { Row and column table }\end{array}$ & $\begin{array}{l}\text { Table with a single row } \\
\text { Table with several rows } \\
\text { and columns }\end{array}$ \\
\hline \multirow[t]{2}{*}{ Time lines } & \multirow[t]{2}{*}{$\begin{array}{l}\text { Visually organize events } \\
\text { in time }\end{array}$} & Simple time line & $\begin{array}{l}\text { Shows events in a linear } \\
\text { organization }\end{array}$ \\
\hline & & Multiple time lines & $\begin{array}{l}\text { Two or more time lines } \\
\text { showing events occur- } \\
\text { ring at the same time in } \\
\text { different contexts }\end{array}$ \\
\hline
\end{tabular}




\section{Note}

Daibao Guo is an assistant professor in the Department of Literacy, Language, and Culture at Boise State University; Katherine Landau Wright is an assistant professor in the Department of Literacy, Language, and Culture at Boise State University; and Erin M. McTigue is a research scientist at the National Reading Research Center of Norway at the University of Stavanger. Correspondence may be sent to Daibao Guo at daibaoguo@boisestate.edu.

\section{References}

Alonzo, A. C., Bennett, L., Kracht, J. B., \& White, W. E. (2016a). myWorld social studies (grade 3). Boston: Pearson.

Alonzo, A. C., Bennett, L., Kracht, J. B., \& White, W. E. (2016b). myWorld social studies (grade 5). Boston: Pearson.

Apple, M. W., \& Christian-Smith, L. K. (Eds.). (1991). The politics of the textbook. New York: Routledge.

Armbruster, B. B., Anderson, T. H., \& Meyer, J. L. (1991). Improving content-area reading using instructional graphics. Reading Research Ouarterly, 26, 393-416.

Atkinson, R. K., Levin, J. R., Kiewra, K. A., Meyers, T., Kim, S., Atkinson, L. A., . . Hwang, Y. (1999). Matrix and mnemonic text-processing adjuncts: Comparing and combining their components. Lournal of Educational Psychology, 91, 342-357.

Baker, F. W. (2012). Media literacy in the K-12 classroom. Washington, DC: International Society for Technology in Education.

Bishop, R. S., \& Hickman, J. (1992). Four to fourteen or forty: Picture books are for everyone. In S. Benedict \& L. Carlisle (Eds.), Beyond words: Picture books for older readers and writers (pp. 1-10). Portsmouth, NH: Heinemann.

Bissell, K. L. (2000). A return to "Mr. Gates": Photography and objectivity. Newspaper Research Lournal, 21, 81-93.

Blank, R. K. (2012). What is the impact of decline in science instructional time in elementary school. Noyce Foundation. Retrieved from http://www.csss-science.org/downloads/NAEPElemScience Data.pdf

Brugar, K. A., \& Roberts, K. (2014). Timelines: An opportunity for meeting standards through textbook reading. Social Studies, 105, 230-236.

Brugar, K. A., \& Roberts, K. L. (2014). Teaching and learning with maps: Improve-a-text. Geography Teacher, 11, 164-167.

Brugar, K. A., \& Roberts, K. L. (2015). Let's table it: Using tables to reflect on informational reading. Oregon Journal for the Social Studies, 3, 31-52.

Brugar, K. A., \& Roberts, K. L. (2017). Seeing is believing: Promoting visual literacy in elementary social studies. Lournal of Teacher Education, 68, 262-279.

Callow, J. (2008). Show me: Principles for assessing students' visual literacy. Reading Teacher, 61, 616-626.

Carney, R. N., \& Levin, J. R. (2002). Pictorial illustrations still improve students' learning from text. Educational Psychology Review, 14, 5-26.

Clark, J. M., \& Paivio, A. (1991). Dual coding theory and education. Educational Psychology Review, 3, 149-210.

Coleman, J. M., \& Dantzler, J. A. (2016). The frequency and type of graphical representations in science trade books for children. Lournal of Visual Literacy, 35, 24-41.

Coleman, J. M., McTigue, E. M., \& Smolkin, L. B. (2011). Elementary teachers' use of graphical representations in science teaching. Iournal of Science Teacher Education, 22, 613-643.

Concannon, S. J. (1975). Illustrations in books for children: Review of research. Reading Teacher, 29, 254-256.

DiSpezio, M., Heithaus, M., \& Frank, M. (2014a). Science fusion (Texas ed., grade 3). Orlando, FL: Houghton Mifflin Harcourt. 
DiSpezio, M., Heithaus, M., \& Frank, M. (2014b). Science fusion (Texas ed., grade 5). Orlando, FL: Houghton Mifflin Harcourt.

Duke, N. K. (2000). 3.6 minutes per day: The scarcity of informational texts in first grade. Reading Research Quarterly, 35, 202-224.

Duke, N. K., \& Billman, A. K. (2009). Informational text difficulty for beginning readers. In Hiebert, E. H., \& Sailors, M., (Eds.), Finding the right texts: What works for beginning and struggling readers (pp. 109-128). New York: Guilford.

Erstad, O. (2012). The learning lives of digital youth-Beyond the formal and informal. Oxford Review of Education, 38, 25-43.

Fang, Z. (1996). Illustrations, text, and the child reader: What are pictures in children's storybooks for? Reading Horizons, 37, 130-142.

Fang, Z., \& Schleppegrell, M. J. (2010). Disciplinary literacies across content areas: Supporting secondary reading through functional language analysis. Iournal of Adolescent and Adult Literack, 53, 587-597.

Fingeret, L. (2012). Visuals in children's informational texts: A content analysis (Unpublished doctoral dissertation). Michigan State University, East Lansing.

Fisher, D., \& Frey, N. (2012). Text complexity and close readings. Newark, DE: International Reading Association. Retrieved from http://education.ucf.edu/mirc/docs/fisher_and_frey_january _2012.pdf

Gardner, R. C. (2001). Psychological statistics using SPSS for Windows. Upper Saddle River, NJ: Prentice Hall.

Gerber, R., Boulton-Lewis, G., \& Bruce, C. (1995). Children's understanding of graphic representations of quantitative data. Learning and Instruction, 5, 77-100.

Guo, D., Zhang, S., McTigue, E., \& Wright, K. L., (2017, April). Do you get the picture?: A metaanalysis of the effect of graphics on reading comprehension. Paper presented at the American Educational Research Association Conference, San Antonio.

Hannus, M., \& Hyönä, J. (1999). Utilization of illustrations during learning of science textbook passages among low-and high-ability children. Contemporary Educational Psychology, 24, 95-123.

Harber, J. R. (1983). The effects of illustrations on the reading performance of learning disabled and normal children. Learning Disability Quarterly, 6, 55-60.

Harmon, J. M., Hedrick, W. B., \& Fox, E. A. (2000). A content analysis of vocabulary instruction in social studies textbooks for grades 4-8. Elementary School Journal, 100, 253-271.

Hayes, D. A., \& Reinking, D. (1991). Good and poor readers' use of graphic aids cued in texts and in adjunct study materials. Contemporary Educational Psychology, 16, 391-398.

Heafner, T. L., \& Fitchett, P. G. (2012). Tipping the scales: National trends of declining social studies instructional time in elementary schools. Journal of Social Studies Research, 36, 190-215.

Hegarty, M., Carpenter, P. A., \& Just, M. A. (1996). Diagrams in the comprehension of scientific text. In R. Barr, M. L. Kamil, P. B. Mosenthal, \& P. D. Pearson (Eds.), Handbook of reading research (Vol. 2). New York: Longman.

Hiebert, E. H. (2005). State reform policies and the task textbooks pose for first-grade readers. $\underline{E l}$ ementary School Journal, 105, 245-266.

Holmes, B. C. (1987). Children's inferences with print and pictures. Lournal of Educational Psychology, 79, 14-18.

IBM SPSS Statistics for Windows (Version 23.0) [Computer software]. Armonk, NY: IBM Corp.

Jeong, J., Gaffney, J. S., \& Choi, J. O. (2010). Availability and use of informational texts in second-, third-, and fourth-grade classrooms. Research in the Teaching of English, 44(4), 435-456.

Jian, Y. C. (2016). Fourth graders' cognitive processes and learning strategies for reading illustrated biology texts: Eye movement measurements. Reading Research Quarterly, 51, 93-109.

Jian, Y. C., \& Ko, H. W. (2017). Influences of text difficulty and reading ability on learning illustrated science texts for children: An eye movement study. Computers and Education, 113, 263-279.

Kulhavy, R. W., Lee, J. B., \& Caterino, L. C. (1985). Conjoint retention of maps and related discourse. Contemporary Educational Psychology, 10, 28-37.

Larkin, J. H., \& Simon, H. A. (1987). Why a diagram is (sometimes) worth ten thousand words. Cognitive Science, 11, 65-99. 
Lawrence Hall of Science. (2014a). Science resources (Texas ed., grade 3). Nashua, NH: Delta Education.

Lawrence Hall of Science. (2014b). Science resources (Texas ed., grade 5). Nashua, NH: Delta Education.

Levin, J. R., Anglin, G. J., \& Carney, R. N. (1987). On empirically validating functions of pictures in prose. Psychology of Illustration, 1, 51-85.

MacDonald, P. L., \& Gardner, R. C. (2000). Type I error rate comparisons of post hoc procedures for I $\times$ J chi-square tables. Educational and Psychological Measurement, 6o, 735-754.

Maloch, B. (2008). Beyond exposure: The uses of informational texts in a second-grade classroom. Research in the Teaching of English, 42, 315-362.

Mangen, A., Walgermo, B. R., \& Brønnick, K. (2013). Reading linear texts on paper versus computer screen: Effects on reading comprehension. International Journal of Educational Research, 58, 61-68.

Mayer, R. E. (2002). Multimedia learning. Psvchologv of Learning and Motivation, 41, 85-139.

Mayer, R. E., \& Gallini, J. K. (1990). When is an illustration worth ten thousand words? Iournal of Educational Psychology, 82, 715-726.

McHugh, M. L. (2013). The chi-square test of independence. Biochemia Medica, 32, 143-149.

McTigue, E. M., \& Flowers, A. C. (2011). Science visual literacy: Learners' perceptions and knowledge of diagrams. Reading Teacher, 64, 578-589.

Metros, S. E. (2008). The educator's role in preparing visually literate learners. Theorv into Practice, 47, 102-109.

Moodley, V. (2013). In-service teacher education: Asking questions for higher order thinking in visual literacy. South African Journal of Education, 33, 1-17.

Myers, C. B., Dougan, A. M., Barber, C. R., Dumas, W., Helmkamp, C. J., Lane, J. W., . . . Theisen, R. (2002). National standards for social studies teachers (Vol. 1). Silver Springs, MD: National Council for the Social Studies.

National Council for the Social Studies. (2013). The College, Career, and Civic Life (C3) framework for social studies state standards: Guidance for enhancing the rigor of $\mathrm{K}-12$ civics, economics, geography, and history. Silver Spring, MD: Author.

NGSS Lead States. (2013). Next generation science standards: For states, by states. Washington, DC: National Academies. doi:10.17226/18290

Nikolajeva, M., \& Scott, C. (2000). The dynamics of picture book communication. Children's Literature in Education, 31, 225-239.

Norman, R. R. (2010). Picture this: Processes promoted by graphics in informational text. Literacy Teaching and Learning, 14, 1-39.

Norman, R. R. (2012). Reading the visuals: What is the relationship between graphical reading processes and student comprehension? Reading and Writing, 25, 739-774.

Palincsar, A. S., \& Duke, N. K. (2004). The role of text and text-reader interactions in young children's reading development and achievement. Elementary School Journal, 105, 183-197.

Pappas, C. C. (2006). The information book genre: Its role in integrated science literacy research and practice. Reading Research Ouarterly, 41, 226-250.

Pearson, P. D., \& Hiebert, E. H. (2014). The state of the field: Qualitative analyses of text complexity. Elementary School Journal, 115, 161-183.

Peeck, J. (1993). Increasing picture effects in learning from illustrated text. Learning and Instruction, 3, 227-238.

Reid, D. J., \& Beveridge, M. (1986). Effects of text illustration on children's learning of a school science topic. British Journal of Educational Psychology, 56, 294-303.

Roberts, K. L., \& Brugar, K. A. (2014). Navigating maps to support comprehension: When textbooks don't have GPS. Geography Teacher, 11, 149-163.

Roberts, K. L., \& Brugar, K. A. (2017). The view from here: Emergence of graphical literacy. Reading Psychology, 38, 733-777.

Roberts, K. L., Norman, R. R., \& Cocco, J. (2015). Relationship between graphical device comprehension and overall text comprehension for third-grade children. Reading Psychology, 36, 389-420. 
Roberts, K. L., Norman, R. R., Duke, N. K., Morsink, P., Martin, N. M., \& Knight, J. A. (2013). Diagrams, timelines, and tables_-Oh, my! Fostering graphical literacy. Reading Teacher, 67, 12-24.

Sadoski, M., \& Paivio, A. (2013). Imagery and text: A dual coding theory of reading and writing. New York: Routledge.

Sadker, D. M., Zittleman, K., \& Sadker, M. P. (2012). Teachers, schools, and society. New York: McGraw-Hill Higher Education.

Shanahan, T., \& Shanahan, C. (2008). Teaching disciplinary literacy to adolescents: Rethinking content-area literacy. Harvard Educational Review, 78, 40-59.

Shanahan, T., \& Shanahan, C. (2012). What is disciplinary literacy and why does it matter? Topics in Lanquage Disorders, 32, 7-18.

Slough, S.W., \& McTigue, E. M. (2013). Development of the graphical analysis protocol (GAP) for eliciting the graphical demands of science textbooks. In M. S. Khine (Ed.), Critical analysis of science textbooks: Evaluating instructional effectiveness (pp. 17-32). New York: Springer.

Slough, S. W., McTigue, E. M., Kim, S., \& Jennings, S. K. (2010). Science textbooks' use of graphical representation: A descriptive analysis of four sixth grade science texts. Reading Psychology, 31, 301-325.

Snodgrass, J. G., \& Vanderwart, M. (1980). A standardized set of 260 pictures: Norms for name agreement, image agreement, familiarity, and visual complexity. Journal of Experimental Psychology, 6, 174-215.

Sontag, S. (1977). On photography. New York: Macmillan.

Strauss, A., \& Corbin, J. (1998). Basics of qualitative research: Techniques and procedures for developing grounded theory. Thousand Oaks, CA: Sage.

Stylianidou, F. (2002). Analysis of science textbook pictures about energy and pupils' readings of them. International Journal of Science Education, 24, 257-283.

Thompson, B. (1988). Misuse of chi-square contingency-table test statistics. Educational and Psychological Research, 8, 39-49.

United States history. (Florida ed., grade 5). (2013). New York: McGraw-Hill.

Vekiri, I. (2002). What is the value of graphical displays in learning? Educational Psvchologv Review, 14, 261-312.

Walden, S. (2012). Photography and knowledge. Lournal of Aesthetics and Art Criticism, 70, 139149.

Walpole, S. (1998). Changing texts, changing thinking: Comprehension demands of new science textbooks. Reading Teacher, 52, 358-369.

Wright, K., Hodges, T., \& Coleman, J. (2017, November). Are the rich still getting richer? The number of books available in first, third and fifth grade classroom libraries. Paper presented at the Association of Literacy Educators and Researchers annual conference, St. Petersburg, FL.

Yeh, Y. F. Y., \& McTigue, E. M. (2009). The frequency, variation, and function of graphical representations within standardized state science tests. School Science and Mathematics, 109, 435449 . 